\title{
Action towards hope: Addressing learner behaviour in a classroom
}

\author{
Authors: \\ Raelene LeeFon ${ }^{1}$ \\ Lynette Jacobs ${ }^{1}$ \\ Adré le Roux ${ }^{1}$ \\ Corene de Wet ${ }^{2}$
}

\section{Affiliations:}

${ }^{1}$ School of Education Studies, University of the Free State, Bloemfontein Campus,

South Africa

${ }^{2}$ School of Open Learning, University of the Free State, Bloemfontein Campus, South Africa

\section{Correspondence to:}

Lynette Jacobs

Email:

jacobsl@ufs.ac.za

\section{Postal address:}

PO Box 339, Bloemfontein

9301, South Africa

Dates:

Received: 04 Dec. 2012

Accepted: 11 June 2013

Published: 12 Nov. 2013

How to cite this article: LeeFon, R., Jacobs, L., Le Roux, A. \& De Wet, C., 2013, 'Action towards hope: Addressing learner behaviour in a classroom', Koers - Bulletin for Christian Scholarship 78(3), Art. \#459, 8 pages. http://dx.doi. org/10.4102/koers.v78i3.459

\section{Note:}

Although this article is based on the research done for the first author's MEd, the article was written from scratch for this supplementum. We referred to the original work at the start of the article to acknowledge it. The first author gave written permission for the article to be written and submitted to Koers. We also put this article through Turnltin to check for plagiarism, and it was cleared with green status.

\section{Read online:}

Unruly learners and disciplinary problems are an intractable part of every teacher's teaching experience. It appears that, even though most schools have enacted a code of conduct to regulate learner behaviour, this does not always have the desired effect. Disciplinary problems in schools impact negatively on the teaching and learning environment as well as on teachers' personal and professional well-being and morale. Framed within the context of a biblical worldview, this article narrates the experiences of one teacher who decided to take action towards hope. The situation in her classroom was quite desperate with learners coming to school unprepared and behaving very badly and parents being uninterested in the performance of their children at school. She realised that she could not change the learners or their parents unless she started with herself. In this context, she, as a postgraduate student under the supervision of the co-authors, embarked on an action-research project to promote positive learner behaviour. By collaborating with the learners on a set of classroom rules, engaging in reflective teaching and changing her own behaviour towards the learners, the situation in her classroom improved. Based on her experiences, this article argues that teachers should empower themselves with knowledge and a better understanding of the concept of discipline rather than viewing the classroom as a battlefield. It is important to acknowledge and show respect and appreciation for each learner in his or her own context.

Die hantering van leerdergedrag in 'n klaskamer: Die pad na hoop. Onordelike leerders en dissiplinêre probleme is onlosmaaklik deel van elke opvoeder se onderrigervaring. Hoewel die meeste skole 'n gedragskode tot hulle beskikking het om leerdergedrag te reguleer, wil dit voorkom asof dit nie altyd die verlangde uitwerking het nie. Dissiplinêre probleme in skole het 'n negatiewe invloed op die onderrig- en leeromgewing asook op opvoeders se persoonlike en professionele welstand en moraal. Hierdie artikel, wat deur 'n Bybelse wêreldbeskouing gerig word, beskryf die ervaringe van 'n opvoeder wat besluit het om 'n reis na hoop te volg. Die situasie in haar klaskamer was hopeloos, leerders het onvoorbereid skool toe gekom en hulle aan wangedrag skuldig gemaak en ouers het belangstelling in die onderwys van hulle kinders verloor. Sy het besef dat sy met haarself moet begin indien sy die situasie wil verander. Teen dié agtergrond het sy onder leiding van die mede-outeurs ' $n$ aksienavorsingsprojek geloods. Die doel van die projek was om positiewe leerdergedrag te bevorder. Deur in samewerking met haar leerders klaskamerreëls op te stel, haar tot reflektiewe onderrig te verbind en haar gedrag teenoor die leerders te verander, het die situasie in haar klaskamer verbeter. Op grond van haar ervaringe word daar in hierdie artikel aangevoer dat opvoeders hulle deur die verkryging van kennis en insig oor dissipline moet bemagtig eerder as om die klaskamer as 'n slagveld te beskou. Dit is belangrik om elke leerder se individualiteit te erken en respek en waardering vir sy of haar unieke omstandighede te toon.

\section{Introduction}

Although most schools seem to have a code of conduct, at least on paper, research indicates that learner misbehaviour is rife in schools (e.g. Joubert \& Serakwane 2009:125; Mestry \& Khumalo 2012:105-108). Marais and Meier (2010:41) claim that ' $[\mathrm{m}]$ isbehaving learners and disciplinary problems are a disproportionate and intractable part of every teacher's experience of teaching'. Learner misbehaviour impacts negatively on teaching and learning (Rossouw 2003:413; Smit 2010:47). Many teachers do not enjoy their work, are under pressure, are absent from school and even quit the teaching profession as a result of their inability to maintain discipline in their classes (Naong 2007:297; Serakwane 2007:3).

After the transition to a democratic dispensation in South Africa, decentralised governance power was given to representative school governing bodies (SGBs) (Joubert \& Prinsloo 2008:74-75;

Copyright: (C 2013. The Authors. Licensee: AOSIS OpenJournals. This work is licensed under the Creative Commons Attribution License. 
Republic of South Africa 1996, s. 16[1]). SGBs have a duty to promote the best interests of schools and provide quality education (Republic of South Africa 1996, s. 20[1] \{a\}). The SGB is, inter alia, responsible for the adoption of a code of conduct for learners at the school as part of their policymaking duties (Republic of South Africa 1996, s. 20[1] \{d\}). SGBs should furthermore 'play an important role in the establishment and maintenance of sound discipline' (Joubert \& Prinsloo 2008:92). Mestry and Khumalo (2012:102-109), however, found that SGBs have difficulty in designing and implementing workable codes of conduct. Parent-governors are disconnected from the daily operations of the schools, and teachers appear to have little confidence in the effectiveness of these codes.

\section{Context and rationale for the study}

Raelene (first author) was teaching at Mundane Primary (pseudonym) when she enrolled for a Master's degree at the University. The school is a former Model C school in a suburb of a small city. There are approximately 600 learners in the school, comprising boys and girls from different races, religions, cultural groups and family structures. The school uses English as the medium of instruction, but for many learners, it is their second or third language. The staff members include females and males from various races with the females being in the majority, and the years of experience ranged from $2-40$.

The discipline situation at Mundane Primary was a reason for concern $^{1}$ (LeeFon 2012:4-5; 23-24). Raelene and some of her colleagues felt helpless and frustrated by the unruly behaviour of the learners. Theft and vandalism were rated as serious discipline problems that teachers encountered. Teachers, including Raelene, were often the victims of theft, and their vehicles were regularly vandalised. In the classrooms, teachers were constantly confronted by learners who acted destructively and disrespectfully towards them and their peers. Some teachers believed the existing code of conduct served no purpose. They also assumed that many of the learners' parents were not only uninvolved but in fact undermined their authority. There were some teachers who gave up trying to regulate the learners, and this made it even more difficult for the teachers who were trying to maintain order in their classes. Typical problems that they experienced were learners talking nonstop in class, learners reacting rudely when being reprimanded and learners showing little or no interest in their school work. Teachers were spending a disproportionate amount of time dealing with unruliness (LeeFon 2012:45-50).

During unstructured interviews with members of staff, a number of behavioural problems were highlighted. These included learners telling lies and disrupting classes. The participants believed that some learners were habitually

1.Whilst the focus of the action-research project was on Raelene's own observations, experiences and reflections, centralising the ' $I$ ' (McNiff \& Whitehead 2006:15) in experiences and reflections, centralising the 'N (McNiff \& Whitehead 2006:15) in from the varion from the various phases (LeeFon 2012:4-5; 23-24). The insights gained during the group interviews do not constitute the focus of this article but merely serve to provide the context of and rationale for the study. destroying school property, particularly in the classrooms. They defaced the desks by scratching their names or swear words on them. Participants also pointed out that the classrooms and passageways were defaced with obscenities and the names of learners. Some teachers said that they did not dare to reprimand a learner, for fear of their vehicles being vandalised. Learners often stole stationery from their peers. They were reported to be extremely arrogant: scratching off the owner's name and writing their own name on stolen stationery. They also stole lunch and money from their peers and sometimes even from their teachers (LeeFon 2012:45-50).

The situation in Raelene's Grade 4 class was just as desperate. The learners were coming to school unprepared, and they behaved very badly during lessons. Raelene felt anxious and dreaded going to work. She furthermore felt isolated, believing that she had no support from the school or the parents. This caused a negative attitude towards the learners and the teaching profession (own reflections). Raelene realised that she could not change the learners or their parents without starting with herself. In this context, Raelene as a postgraduate student, under supervision of the co-authors, embarked on an action-research project to promote positive learner behaviour by focusing firstly on her own behaviour. With the support from her supervisors, she examined her own practices with the aim of changing the way in which she dealt with discipline, in order to engage the learners and negotiate with them to bring about a positive transformation in her class. The overall research question that she posed was: How can discipline practices be adapted in the context of the classroom to effectively promote good learner behaviour?

\section{Action research and objectives of the study}

Action research is a type of examination that allows people to scrutinise and assess their work (McNiff \& Whitehead 2006:7), working towards solving, inter alia, specific educational problems (Creswell 2008:597). Action research emphasises the individual as the heart of the investigation (McNiff \& Whitehead 2006:15), and as such, Raelene formed the focus of our research. The action-research cycle was followed. This entails a cycle of observing, planning, implementing and reflecting (McNiff \& Whitehead 2006:9) or, as Creswell (2008:604) explains, a 'spiral of looking, thinking and action'.

The objectives of the study were two-fold. Firstly, the study aimed at improving the situation in Raelene's classroom by looking, thinking and acting. In line with the action-research cycle, the following questions guided her in each of two cycles:

- What is the situation regarding the management of learner behaviour in my classroom?

- What can be done towards improving the current situation?

- What effects do these strategies have on the situation once implemented? 
Secondly, we wanted to provide some guidelines for teachers towards improving the discipline in their own context. The first objective is dealt with under 'findings' whilst the second objective is addressed under 'discussion and recommendations'.

\section{Theoretical framework}

Framed within a biblical worldview, this study was premised on the central realities of an orderly creation that is cursed by sin but longing for redemption (Dooyeweerd 1979; Wolters 1990). The two key concepts that notate these biblical themes and inform this research are structure and direction. Whilst structure denotes the structural order of creation, that is, the essence or proper functions of a diversity of societal institutions, such as, inter alia the school, the state and the church, direction refers to the deviation from that structural ordinance (Wolters 1990:73). Aligned with the biblical compass of creation, fall and redemption, the distinction between structure and direction is drawn together by the possibility of a redirection of the derivation of the unique nature of creational structures to their very essence. From a biblical perspective, this restoration of creational structures would typically be attributed to grace.

As our daily experiences are constituted by a pull between structural aims and directional distortion, the distinction between structure and direction is significant for the school in general, and for this research in particular. All schools have certain distinctive features that not only constitute their existence within an orderly creation as the 'school' but also attune teachers intuitively to its normative structure (cf. Wolters 1990:23). On the basis of the ontological perspective of an orderly creation that underlies 'the great diversity of societal forms in different cultures and periods of history', it is accepted that the school emerged through historical development and is qualified by its task to disclose the learners' logical capacity of subjective functioning (Schoeman 1980:39; Puolimatka 1995:85; Wolters 1990:80).

Thus, for Raelene finding herself in a multicultural school setting, she was intuitively aware that her primary task as a teacher is to centralise learning in her classroom. She realised her obligation to ensure that, through her pedagogical actions, the academic achievement of all learners should be raised (Nieto \& Bode 2008:10). It was also this intuitive awareness that enabled her to recognise the negative impact of learner misbehaviour on teaching and learning. By implication, Raelene was able to recognise how the 'violation' of the very essence of the school renders its primary function counterproductive. Her decision to take action and to promote positive learner behaviour by focusing on her own behaviour was motivated by hope. Thus, it was through the examination of, and change in, her behaviour as a teacher that Raelene started to redirect her classroom practices towards their structural goal, namely to centralise learning in her classroom.

Raelene's action of hope underscores the liberating message that the distortion of the primary task of the school is located only in the direction distinction whilst the uncompromised creational structure of the school offers a way out of practices that hamper effective teaching and learning.

\section{The research methods}

By framing this study within a biblical worldview, Raelene was provided with the possibility and thus the hope that classroom practices can be redirected towards the structural goal of the school. However, the intention was not only to give Raelene hope for improving her own situation. By sharing her experiences and insights, we want to encourage teachers to reflect on their own practices, and we want to show how these practices can be redirected towards the very essence of classroom practice, namely effective teaching and learning.

We used Raelene's observations extensively as data. Observation is the organised process wherein researchers make use of their senses and insight to gather actual evidence by observing the participants in the research location (Creswell 2008:643). Raelene observed herself and the interaction between her and the learners in various class settings, and she then recorded these in a journal. The observations led to our literature review in order to draw from what is known, together with reflections diarised by Raelene.

Reflections are constructed on feelings and instinct. In a study of this kind, the researcher is in the best position to analyse and comment on the greater significance of the data (Creswell 2008:265). During the action-research cycles, we specifically used these reflections to evaluate the implemented plan of action.

We focused on a number of aspects to promote the integrity of the study. Firstly, trustworthiness was enriched by not permitting unsubstantiated inferences to obscure the way of the research and thus distort the findings of the study (Nieuwenhuis 2008:86). Keeping a reflective journal assisted Raelene to focus her thoughts. We selected quotations wisely (Nieuwenhuis 2008:115) in an attempt to convey what was actually meant by the participants or by Raelene so that the researchers' own interpretations do not dominate.

We also used a critical reader as an external auditor to review the project at several stages and to evaluate the findings of this paper; this is in line with Creswell's recommendation (2008:267) so as to enhance its credibility. External auditing involves an individual 'outside the study to review different aspects of the research' and who reports back in writing on issues such as the logic of the inferences, the appropriateness of the themes and the justification of the decisions. We furthermore saw the presentation of the provisional paper at the 'Sustainable Rural Learning Ecologies Colloquium', held on the QwaQwa campus of the University of the Free State during October 2012, as a form of external auditing and took note of the feedback that we received. 
In research involving human beings, ethical considerations are vast and complex (Strydom 2011:115). Creswell (2008:11-13) states that, throughout the research process, the researcher should follow ethical practices such as respecting the rights of respondents, honouring the research sites that are visited and reporting research findings fully and honestly. Wassenaar (2006:67) stresses the importance of the philosophical principles that guide ethical research. These principles include autonomy and respect for the dignity of persons, avoiding possibilities of harming others and beneficence and justice.

Although Raelene's own attitudes and actions were at the heart of this study, it had the potential to affect the learners in her classroom. The purpose of this study was to improve the situation in Raelene's classroom, and thus, the study had the possibility of benefiting the learners as well (Wassenaar 2006:67). Raelene focused on treating everybody involved with dignity and respect, as valued individuals in the research process. Written informed consent was obtained from the parents of each of the learners in her class as well as from the school principal and the relevant provincial Department of Education (cf. Strydom 2011:117-118). For the duration of the study, Raelene held debriefing sessions with the learners to allow them to enter into an equal communicative situation to discuss the experience and the progress that was being made (Strydom 2011:122). We undertook to protect the identities of everybody involved (excluding ourselves) and thus did not disclose the name of the school, the city or the province in which the study was undertaken. Any information that could lead to the identification of any participant has been withheld from this report (Strydom 2011:119-121). Raelene, who is also the first author of this article, gave consent to her co-researchers that the findings of this study may be placed in the public domain.

\section{Findings}

The dissemination of the findings of the action-research project was directed by McNiff and Whitehead's (2006:15) guidelines for reporting on action research. The subsequent discussion will tell the story of Raelene's journey towards improving the situation in her classroom.

\section{Looking}

During the first cycle of the project, Raelene gathered information on the status quo in her classroom and school. This led us to conduct an extensive literature review. The knowledge and insight into the theory of learner discipline as well as the principles of action research guided her actions to improve learner behaviour in her classroom. Critical reflection, based on notes in her reflective journal, led her to greater insights into herself as well to greater insight into her learners.

\section{The situation in Raelene's class}

At the onset of this research project, Raelene felt helpless, frustrated and isolated. Whilst she intuitively realised that teaching and learning were rendered ineffective in her classroom, she also gathered that the learners were aware that there were no consequences when they misbehaved. She noted in her reflective diary, during the first few days of the project, that she was overwhelmed by the situation in her class and negative towards her profession. The amount of administration work and the marking and preparation of lessons left her short-tempered and irritable. The learners were talking nonstop, even when they had work to complete, and most of them did not bother to complete their work at school or at home. The boys in the class fought a great deal, and a number of the girls displayed aggressive behaviour. The learners reacted defiantly when reprimanded, and they would backchat and give Raelene defiant looks. Learners were even swearing at Raelene under their breath.

In order to plan how to address the precarious situation in Raelene's class, we undertook a literature review, firstly, to obtain a common understanding of the concept of discipline and, secondly, to identify possible strategies that Raelene could follow to address learner misbehaviour in her classroom.

\section{The concept of discipline}

According to Mtsweni (2008:28), discipline is vital for maintaining order. The concept discipline is sometimes used to refer to the intention to suppress and redirect learners' misbehaviour (Mtsweni 2008:19) or at least to control children so as to preserve order in the school (Serakwane 2007:27) through corrective measures (Masitsa 2008:244). However, others explain discipline as positive behaviour, intended to promote proper conduct, order and fairness in line with the conventional rules of good behaviour towards the growth of a learner's self-control (Davidowitz 2007:5; Joubert \& Squelch 2005:2; Masitsa 2008:265). We view order as necessary to create an environment conducive to teaching and learning, and teachers should enable such an orderly environment. This critical role of order also resonates with the underlying biblical assumption of an orderly creation. Thus, within the context of Raelene's study, it could be argued that problems surrounding, inter alia, indiscipline necessitate the redirection of classroom practices in such a way that the desirability of an orderly classroom, and subsequently an orderly society, will be highlighted (cf. Schoeman 2011). Our understanding of discipline is in line with the second group of authors, and we argue that teachers should focus on promoting positive behaviour rather than penalising negative behaviour, and this informed Raelene's strategy.

The erosion or the complete absence of values is proposed in the literature as fundamental to the discipline problems experienced in schools (Mohapi 2007:9; Mtsweni 2008:37). It is concomitantly suggested that instilling a particular value system in schools would encourage an understanding of what is right and what is wrong (Du Preez \& Roux 2010:13; Joubert \& Serakwane 2009:134). Values such as respect and responsibility will inspire learners to be and act responsibly 
towards themselves, others and their school (Joubert, De Waal \& Rossouw 2004:85; Psunder 2005:275).

Rules are requirements for discipline as they denote how learners are expected to behave and what they are not allowed to do (Leung \& Lee 2006:49). A disciplinary policy, such as a code of conduct, could assist in this with its rules and consequences (Republic of South Africa 1996, s. 8) to create order in schools and classrooms. Mtsweni (2008:28) believes that learners will come to understand the necessity for order in the world. They would then realise that, in terms of that order, some forms of behaviour are acceptable whilst others are not. When discipline is encouraged, it develops a sense of personal responsibility that establishes a sense of order in the life of the learner (De Waal 2011:176), and it enhances self-control.

Bear and Duquette (2008:10) refer to self-control as 'assuming social and moral responsibility for one's own actions, and doing so under one's own volition'. Self-control can be achieved when teachers assist the learners to develop it (Mabeba \& Prinsloo 2000:35). Bear and Duquette (2008:10) believe that teachers can help learners to gain self-control through the development of learners' discernment of right and wrong, by encouraging them to take responsibility for their actions and by guiding them in identifying the importance of relationships. Learners also learn to deal with their own feelings as well as those of their fellow learners and teachers (Mtsweni 2008:27). This will inform the values that learners could internalise.

Guiding values and school rules inform strategies to promote positive learner behaviour.

\section{Discipline strategies}

Msani (2007:26) argues that the stakeholders of the school must understand that disciplinary methods used in schools should be based on the intention of altering the conduct of learners in a positive manner. In order for disciplinary strategies to be successful, they should be useful and suitable (Masitsa 2008:239). Whilst a number of strategies towards the management of learner behaviour exist, one should also be aware of the pitfalls in this regard.

The relationship between the teacher and learner is central to teaching and learning (Mohapi 2007:157) in order to foster mutual respect between the parties and to establish positive discipline in the classroom (Joubert \& Serakwane 2009:134). Such a relationship is based on the ways in which teachers relate to different and various learners (Serakwane 2007:59). However, this does not imply that teachers should try to become friends with their learners (Bru, Stephens \& Torsheim 2002:289).

Whilst the task of maintaining discipline in the classroom often appears to be the sole responsibility of the teacher (Serakwane 2007:63), learners should be given the opportunity to be responsible for their own actions, to build up their self- esteem and to consider their actions. By creating the space for learners to be responsible, teachers are giving the learners the chance and education to be accountable (Department of Education [DoE] 2000:14; Joubert \& Serakwane 2009:135).

Successful partnerships between teachers and parents may lead to better academic achievement and positive behaviour (Lemmer 2007:218). It starts with the involvement of parents in the drafting of the code of conduct for learners towards establishing a disciplined environment (Smit 2010:48), but it should also include involving the parents in the management of their child's behaviour (Joubert \& Serakwane 2009:134).

Joubert and Serakwane (2009:135) suggest that teachers should implement a democratic style of teaching and forgo autocratic and permissive teaching styles. Good discipline does not happen by chance as it needs to be purposefully managed (Joubert \& Squelch 2005:2), which includes steady guidance by the teacher and the discouraging of bad behaviour (Serakwane 2007:69). Johannes (2005:29) suggests that teacher and learners should work together in creating classroom rules and the consequences that should be expected if undesirable behaviour occurs. This will give the learners some rights and obligations and might support them in becoming more committed to attain the objectives (Mtsweni 2008:30; Snodgrass \& Haines 2005:33).

The rights of learners are often blamed for the problems in schools (Davidowitz 2007:4). However, a true understanding of the values that inform democracy (DoE 2000:9) and the responsibilities that go hand-in-hand with human rights can be used to the advantage of all. Whereas learners' rights and freedoms should never validate their misbehaviour (Serakwane 2007:29), teachers should also be critical of their own behaviour. Harsh and insulting words can impact negatively on learners (Joubert \& Serakwane 2009:131), and teachers should forgo corporal punishment and reactive authoritarian practices (Venter \& Van Niekerk 2011:255). Teachers should, when disciplining a learner, take into account the value of respect for the learners as well as their human dignity so that learners can experience the values as validated in the lives and attitudes of their teachers towards the school and others (Joubert et al. 2004:85; Psunder 2005:275). Venter and Van Niekerk (2011:253) thus argue for using positive and constructive discipline.

\section{Taking action}

Armed with the insight gained through the literature study, but also informed by her own understanding that the essence of her own classroom should be effective teaching and learning, Raelene took action in her classroom to improve the situation. She decided to include the learners in solving the problem whilst at the same time being critical of her own style of discipline.

She handed out a copy of the school's code of conduct to each learner. The class read through it together, and the document was discussed and permanently displayed in the classroom. This discussion and the visual display helped to enforce the 
notion of orderliness whilst simultaneously prompting, by implication, the distinctive direction Raelene's classroom practice intended to take, namely the re-centralisation of teaching and learning in her classroom. The learners were also encouraged to give it to their parents to read. Ten class rules were then negotiated between the learners and Raelene, and these were also displayed in big bold letters. These basic rules were:

1. no walking around unnecessarily

2. put up your hand when you want to ask a question

3. keep quiet when the teacher is giving a lesson and while you are doing your work

4. no fighting

5. always be neat and tidy

6. no playing games in class

7. when you have finished your work, read a book

8. write down all your homework

9. do not leave your books at school or at home

10. no stealing.

Raelene also proposed rules for herself, namely:

1. dress appropriately

2. always be prepared for lessons

3. do not leave the learners unattended

4. treat all learners the same

5. marking and other administrative work should be done during administrative periods and not during class

6. when learners have work to complete, move around in the class and check on them while they are working

7. avoid showing anger towards learners by shouting; instead turn around and cool off.

The learners' rules were reviewed every afternoon once they had written down their homework in their diaries. Raelene's rules were kept in her journal, and she read through them at the end of each day to see whether she had successfully abided by them. It was not easy for Raelene or the learners to constantly abide by the rules, but as they reflected on their successes and failures daily, it became easier.

\section{Thinking}

Based on Raelene's reflective diary, we considered the progress that was made towards an improved situation in the class. She noted that the literature study provided her with knowledge that she could apply in the context of her classroom. She noted: 'I no longer felt helpless and inadequate because I was empowering myself with knowledge.' Through reading the literature, she realised that she was not the only teacher grappling with learner misbehaviour.

She noted: 'Speaking to them instead of shouting seems to work!' However, there were also times when she became despondent:

'I am only human. At times I get so angry that after speaking to the learners about the same thing continuously, all I want to do is vent my anger on the learners. It seemed that the more I tried to change and become better at my profession, the more I was faced with bigger obstacles.'
In spite of her frustration, she realised that some days were better than others. On good days, she remembered why she had become a teacher in the first place. Hope for a better teaching and learning environment increased as she observed that the learners kept on breaking rules, but only specific rules, not all the rules. She then attended to these problems consistently. She noted some signs of positive selfdirected behaviour amongst the learners. She reflected that, ' $[w]$ hen given a choice, the learners often choose to do the right thing'.

She became aware of the influence that her own attitude had on the behaviour of the learners. She wrote down that, when she changed her attitude towards the learners, the situation improved and that 'some of the learners have also changed their attitudes'. The realisation that the majority of the learners were often keeping to most of the agreed-upon rules led her to write the following in her diary:

'If changing my attitude and practice had an influence on some of the learners, then there has to be something that I can do to change the small percentage of learners still misbehaving.'

Inspired by the improvement in her state of mind and the learners' attitude towards her and schooling, she embarked on a second cycle. During the second cycle, she once again observed, took action and reflected on her successes and failures.

\section{Looking}

Inspired by the improvements in her own attitude, and those of most of the learners, Raelene critically re-examined the situation. She observed that the majority of the learners' behaviour was good. Motivated by hope and noting the possibility of slowly redirecting her teaching practice, she reflected on her own behaviour towards the misbehaving learners. She realised that she needed to be more consistent in her demeanour towards them; she needed to treat all learners the same. She also realised that many of the learners were struggling to complete their homework. After revisiting the literature and reflecting on the specific problems of the learners, she took action once again.

\section{Taking action}

The daily discussions on the class rules continued but so did some of the problems. Raelene realised that she should not lose hope. Instead, she should remain willing to make smallscale improvements to her classroom practice. When she realised that the quantity of homework was not as important as the consistency in working, she scaled down slightly on the amount of homework. She also made sure that the homework was taken down before the learners went home. She checked without fail whether the homework had been done.

She always praised good behaviour and performance and informed the parents about transgressions, meticulously recording efforts and offences. Through these records, she was able to identify the few learners who were still not 
performing in line with the agreed-upon rules. She then entered into non-confrontational, individual discussions with the 'problem' learners. During these discussions she emphasised her commitment to help them to act responsibly and to take ownership of their own work and actions. Whilst Raelene's actions helped to lessen the negative impact of learner misbehaviour on teaching and learning, she realised that she needed additional support: five of the learners were still not adhering to the rules. Raelene requested the parents or caregivers to meet her to discuss the behaviour of these learners.

\section{Thinking}

From Raelene's reflective diary, it is clear that promoting positive behaviour instead of punishing learners for misbehaving made her feel more at ease with herself. She noted that she did not feel as though she was at school fighting a war anymore. The learners generally responded positively, and their behaviour basically depended on how the situation was managed. When there was consistency around decisions, actions and the work ethic, most of the learners had the ability to follow the example that Raelene set.

The five learners who were identified as still misbehaving in the class continued to be problematic although some change was observed in some of them. In the cases where the parents or caregivers decided to join forces with Raelene in promoting better behaviour, the 'problem' learners showed improvement. In two cases, the parents or caregivers refused to meet with the school. Although she was not able to convince these parents or caregivers to consult with her, she did try to be supportive and positive towards all learners even though she experienced some setbacks.

\section{Discussion and recommendations}

Framed within the context of a biblical worldview, it may be argued that Raelene's study is illustrative on two accounts. Firstly, the study illustrates the on-going pull between structural aims and directional distortion. In Raelene's class, learner behaviour, including the unwillingness of some learners to cooperate, had a disabling influence on her ability to centralise teaching and learning in her classroom. However, whilst being intuitively attuned to the school's normative structure, Raelene was not only prepared to take action, but through her own reflections, she could observe how addressing learner behaviour had the potential to gradually re-centralise teaching and learning in her classroom.

Based on Raelene's experiences and the insights that we gained in the process, we recommend that schools equip teachers and other stakeholders to embrace reflection as a strategy to gain insight into problems instead of merely reacting to problems. Instead of complaining about the abolition of corporal punishment, schools should review the literature to learn from others. In their classrooms, teachers should not only concentrate on changing the behaviour of their learners but also on changing their own. In this regard, they need to focus on personal strategies such as improving their attitude and other ways to improve their own conduct. Teachers' own attitude, behaviour and stability can indeed promote or discourage positive learner behaviour. They should thus try to be even-tempered, to treat all learners equally and consistently and to record accurately the behaviours of learners as well as their circumstances. They should then try to make responsible and informed decisions based on these records.

Secondly, Raelene's study is illustrative of the liberating message that the creational structure of the school will always remain uncompromised. Hope-in-action is subsequently always strengthened by the insight that, whilst learner misbehaviour can temporarily hamper effective teaching and learning, the possibility of redirecting classroom practices towards effective practices remains. In this regard, we recommend that teachers should focus on the diversity within the school. They should acknowledge the uniqueness of each learner and focus on strategies to engender positive behaviour instead of punitive, degrading measures.

Within the current democratic context, and in line with human rights, schools and teachers should include learners in the development of rules that will encourage positive behaviour instead of using a top-down approach. Collectively, these rules should be regularly and critically revisited and consistently implemented in their classes. Whilst learners should be held accountable for their behaviour, teachers should understand the personal circumstances of the learners and collaborate with parents towards improved learner behaviour. It is our contention that such an affirmative and collaborative approach has the potential to infuse action with hope on two accounts: It will infuse hope in the teacher that, when classroom practice deviates from what is needed for effective teaching and learning, the re-direction thereof is always possible, and it will infuse hope in the learners that teaching in the classroom can indeed be effective for their own learning.

\section{Conclusion}

As we have to accept that the continued tension between the structural integrity of the school and the compromising thereof will persist in this broken and unequal world, the situation at the conclusion of the project was not perfect. However, Raelene's willingness to redirect her own thinking about her role as teacher and her attempts to restore learning as a centralised classroom activity decreased the disciplinary problems in her classroom.

She pledged to reflect continually on herself as a teacher and on her way of thinking and acting. A comment made by one of her colleagues about the discipline in her class encouraged her: 'There is a difference between your class and the other grade 4 class. Your class seems to be so mature and work well on their own'.

It is the task of all teachers to develop own approaches and strategies, to combat the disciplinary problems in their 
classes; however, some lessons can be learnt from others. It is important to acknowledge each learner as a unique individual and to respect and appreciate each learner in his or her own context when addressing disciplinary problems. Consistent enforcement of classroom rules eventually pays off.

Raelene concluded her reflective journal with the following annotation:

'The action research cycle was formally employed in the context of my classroom during one year. I realised the following year that the lessons learned changed the way that I deal with problems and specifically, the way I interact with the learners in class. Whilst learner behaviour remains a challenge, I do not feel so inadequate any more. I constantly take steps to create an atmosphere conducive to teaching and learning in class, resulting in my enjoying teaching once more.'

\section{Acknowledgements}

Our sincere gratitude to Raelene's colleagues who were willing to contribute their time, knowledge and experience and also to the learners in Raelene's class without whose participation this study would not have been possible.

\section{Competing interests}

The authors declare that they have no financial or personal relationship(s) which may have inappropriately influenced them in writing this article.

\section{Authors' contribution}

R.L. (University of the Free State) embarked on an action research project towards her MEd qualification under the supervision of L.J. (University of the Free State) and C.d.W. (University of the Free State). A.l.R. (University of the Free State) joined the team as a third member of the panel to whom R.L. presented her progress at various stages. Based on the larger study, this article was written by the three academic staff members. L.J. (University of the Free State) wrote the bulk of the article, A.l.R. focussed on the theoretical stance on which the article was based and C.d.W. (University of the Free State) provided critical inputs regarding the argumentation and flow of the article.

\section{References}

Bear, G. \& Duquette, J., 2008, 'Fostering self-discipline: Self-discipline, a primary goal of education, helps students' exhibit good behavior in and out of school', in National Association of School and Psychologists, viewed 19 August 2011, from http://www.nasponline.org/resources/principals/nassp_fosteringselfdiscipline. pdf

Bru, E., Stephens, P. \& Torsheim, T., 2002, 'Students' perceptions of classroom management and reports of their own misbehavior', Journal of School Psychology 40(4), 287-307.

Creswell, J.W., 2008, Educational research: Planning, conducting, and evaluating quantitative and qualitative research, Pearson Prentice Hall, Upper Saddle River.

Davidowitz, O., 2007, 'Developing democracy or promoting disruption?: Educators' perceptions of the Dept. of Education's current policy on classroom discipline', MEd dissertation, University of the Witwatersrand.

De Waal, E., 2011, 'Legal accountability for public school discipline: Fact or fiction', South African Journal of Education 31, 175-189.

Department of Education (DoE), 2000, Alternatives to corporal punishment: The learning experience, Government Printers, Pretoria.
Dooyeweerd, H., 1979, Roots of Western culture: Pagan, secular and Christian options, Wedge Pub. Foundation, Toronto.

Du Preez, P. \& Roux, C., 2010, 'Human rights values or cultural values? Pursuing values to maintain positive discipline in multicultural schools', South African Journal of Education 30, 13-26.

Johannes, E.A., 2005, 'Using collaborative action research to improve classroom discipline: An action research study at a secondary school in the Boland', MEd dissertation, University of the Western Cape.

Joubert, R. \& Prinsloo, S., 2008, The law of education in South Africa, Van Schaik, Pretoria.

Joubert, R. \& Serakwane, J., 2009, 'Establishing discipline in the contemporary classroom', Journal of Educational Studies, suppl. ser. 8, 125-137.

Joubert, R. \& Squelch, J., 2005, Learner discipline in schools, Centre for Education Law and Policy, Pretoria.

Joubert, R., De Waal, E. \& Rossouw, J.P., 2004, 'Discipline: Impact on access to equal educational opportunities', South African Journal of Education 22(3), 77-87.

LeeFon, R., 2012, 'Reflecting on the Code of Conduct for Learners: Action towards policy improvement', MEd dissertation, University of the Free State.

Lemmer, E.M., 2007, 'Parent involvement in teacher education in South Africa', International Journal About Parents in Education 1, 218-229.

Leung, C.L. \& Lee, F.W., 2006, 'The co-production of student school rule-breaking behavior', Research in Education 74, 47-58.

Mabeba, M. \& Prinsloo, E., 2000, 'Perceptions of discipline and ensuing discipline problems in secondary education', South African Journal of Education 20(1), 34-41.

Marais, P. \& Meier, C., 2010, 'Disruptive behaviour in the foundation phase of schooling', South African Journal of Education 30(1), 41-57.

Masitsa, G., 2008, 'Discipline and disciplinary measures in the Free State township schools: Unresolved problems', Acta Academica 40(3), 234-270.

McNiff, J. \& Whitehead, J., 2006, All you need to know about action research, Sage Publications, London.

Mestry, R. \& Khumalo, J., 2012, 'Governing bodies and learner discipline: Managing rural schools', South African Journal of Education 32, 97-110.

Mohapi, J., 2007, 'The influence of educators' life experiences on classroom discipline practices', PhD thesis, University of Pretoria.

Msani, M., 2007, 'Discipline in a Kwazulu-Natal secondary school: The gendered experience of learners', MEd dissertation, University of Kwazulu-Natal.

Mtsweni, J., 2008, 'The role of educators in the management of school discipline in the Nkangala region of Mpumalanga', MEd dissertation, University of South Africa.

Naong, M., 2007, 'The impact of the abolition of corporal punishment on teacher morale: 1994-2004', South African Journal of Education 27(2), 283-300.

Nieto, S. \& Bode, P., 2008, Affirming diversity. The socio-political context of multicultural education, 5th edn., Pearson, Boston.

Nieuwenhuis, J., 2008, 'Qualitative research designs and data gathering techniques', in K. Maree (ed.), First steps in research, pp. 86-115, Van Schaik Publishers, Pretoria.

Psunder, M., 2005, 'How effective is school discipline in preparing students to become responsible citizens? Slovenian teachers and students views', Teaching and Teacher Education 21, 273-286.

Puolimatka, T., 1995, Democracy and education: The critical citizen as an educational aim, Suomalainen Tiedeakatemia, Helsinki.

Republic of South Africa, 1996, South African Schools Act (No 84 of 1996), Government Printers, Pretoria.

Rossouw, J.P., 2003, 'Learner discipline in South African public schools: A qualitative study', Koers - Bulletin for Christian Scholarship 68(4), 413-435.

Schoeman, P.G., 1980, An introduction to a philosophy of education, Butterworths, Durban.

Schoeman, P.G., 2011, 'In search of a new morality for South Africa, part v: Values education in education: Realities, impediments and prospects', Journal for Christian Scholarship 47(3/4), 149-170.

Serakwane, J., 2007, 'Establishing discipline in the contemporary classroom', MEd dissertation, University of Pretoria.

Smit, M.E., 2010, 'The role of school discipline in combating violence in schools in the East London region', MEd dissertation, University of Fort Hare.

Snodgrass, L. \& Haines, R., 2005, 'An eclectic model for conflict resolution training in multicultural secondary schools', Commonwealth Youth and Development 3(1), 26-53.

Strydom, H., 2011, 'Ethical aspects of research in the social sciences and human services professions', in A.S. de Vos (ed.), Research at grass roots for the socia sciences and human sciences professions, pp. 113-130, Van Schaik, Pretoria.

Venter, E. \& Van Niekerk, L.J., 2011, 'Reconsidering the role of power, punishment and discipline in South African schools', Koers - Bulletin for Christian Scholarship 76(2), 243-260.

Wassenaar, D.R., 2006, 'Ethical issues in social science research', in M. Terre Blanche, K. Durrheim \& D. Painter (eds.), Research in practice: Applied methods for the social sciences, pp. 60-79, University of Cape Town Press, Cape Town.

Wolters, A., 1990, Creation regained: Biblical basics for a reformational worldview, William B. Eerdmans Publishing Company, Grand Rapids. 